\title{
Variability of morphological traits of mountain Veratrum lobelianum in lowland locality
}

\author{
Alina Stachurska-Swakoń", Kinga Kostrakiewicz-Gieralt, Joanna Świerczek \\ Jagiellonian University, Institute of Botany, Department of Plant Ecology, Gronostajowa $3 \mathrm{St}$, \\ 30-387 Kraków, Poland, "e-mail: alina stachurska-swakon@uj.edu.pl
}

Received: 2 March 2018 / Accepted: 5 May 2018

\begin{abstract}
Veratrum lobelianum is a mountain species occurring mainly in the subalpine and montane zone in European and Asian mountains. In Poland, the species has lowlands localities. Three populations of the species were characterized in the Tarnów Plateau (Sandomierz Basin, southern Poland), growing in oak-hornbeam forest and alder carrs. In the similar climatic conditions but varied light and soil conditions (humidity) the species populations differed in morphological traits as plant height, leaves number, leave dimensions, and inflorescence length. The results extend the published ranges of the traits of the species.
\end{abstract}

Key words: biometry, ecotypes, isolated populations, mountain species, phenotypic plasticity, Tarnów Plateau.

\section{Introduction}

The occurrence of mountain species outside the general range is the interesting phenomenon that attracts scientists when analyzing general or regional flora (Szafer, 1930; Zając, 1996). The causes underlying an origin of local populations, migration routes and time are considered as important questions in plant geography (Szafer, 1930; Kornaś \& Medwecka-Kornaś, 2002; Zemanek, 2009). Additionally, these local populations are exposed to negative intra-population processes due to isolation (Mitka, 1997; Stachurska-Swakoń et al., 2011, 2012) and have to cope with different habitat conditions (Stachurska-Swakon \& Kuź, 2011). There are 122 mountain plant taxa with lowland localities in Poland (Parusel, 2016). To the lowland areas with the highest concentration of mountain taxa belong Kraków-Częstochowa Upland, Nida Basin, Silesian Upland, Opole Plain, Roztocze (Szafer, 1930; Zając, 1996; Nowak et al., 2011). The montane species represent the largest group occurred outside the mountains ranges whereas subalpine and alpine species are not often found (Pawłowska, 1972; Zając, 1996). The localities are usu- ally situated in forest communities, most often in the surrounding of streams (Nowak et al., 2011; Bartoszek et al., 2015), mainly due to more favorable microclimatic conditions (Michalik, 1983).

One of the mountain species occurring in polish lowlands is Veratrum lobelianum. It represents the multizonal group of mountain species in lowland localities, however, some authors treat this species as subalpine (e.g. Pawłowska, 1972). The information of the distribution of the species is found mainly as a result of local flora investigation (e.g. Błaszczyk, 1959; Izdebska, 1963; Kuczyńska, 1974; Jakubowska-Gabara \& Jost-Jakubowska, 1978; Gawłowska et al., 1987; Szwagrzyk, 1987; Bróż \& Przemyski, 1988; Ciaciura, 1988; Wayda, 1996; Urbisz, 2001; Zając et al., 2006; Banach, 2008; Nowak et al., 2011; Jakubowska-Gabara et al., 2012; Kowalczyk, 2012; Pierścińska, 2012; Urban \& Wójciak, 2012, Jarek \& Stachurska-Swakoń, 2016), rarely the detailed habitat conditions are characterized (e.g. Chmura et al., 2011).

Previous studies on the distribution of the species outside the mountainous area in Poland indicate a decrease of number and size of local populations and pointed at 
weaker vitality (Bróż \& Przemyski, 1988). The main cause of threat to existing lowland populations is draining river valleys and marshy areas. Despite growing interest in the distribution of the species outside the mountain area, the present state of knowledge of the populations and habitat conditions is still insufficient. Therefore we undertook the presented investigation, which main goals were: 1. estimation of Veratrum lobelianum resources on the Tarnów Plateau (Sandomierz Basin, southern Poland), 2. range of selected morphological traits in lowland populations.

\section{Material and methods}

\subsection{The studied species}

Veratrum lobelianum Bernh. (Veratrum album L. subsp. lobelianum (Bernh.) Arcang.) is one of the numerous species belonging to the genus Veratrum (Liliales, Melanthiaceae) occurring in the northern hemisphere. Due to the morphological similarity, the division within the genus is unambiguous, and the number of recognized species varies from 30 (Gleason \& Cronquist, 1991) to 48 (Hess et al., 1967). In the case of the taxon being the subject of the study, taxonomists treat it either as a separate species (e.g. Szafer et al., 1986; Mirek et al., 2002) or as a subspecies (Hess et al., 1967; Lauber \& Wagner, 1996).

Veratrum lobelianum is a long-lived perennial hemicryptophytic species with a stout vertical rhizome covered with remnants of old leaf sheaths. The unbranched and robust stem could be almost $2 \mathrm{~m}$ tall. The leaves are large (10-25 $\mathrm{cm}$ ), oblong to elliptic in shape with pointed tips and clasping bases. They are prominently ribbed (accordion pleated). Mature plants produce long paniculate inflorescence with green-yellow flowers. It flowers infrequently every 3-4 years (Łukaszyńska, 1998; 4-8 years in Veratrum album, Hesse et al., 2008). However, it was observed every year flowering during several years in the garden experiment (Stachurska-Swakoń, unpbl). The species produces bisexual flowers (protandrous) and smaller male flowers. The flowers are pollinated by insects from Diptera order (Takhtajan, 1982). The type of produced fruit is a capsule with numerous seeds bearing winglike structures and dispersed by wind. The seeds are eaten by butterfly larvae from Geometridae family (Varienik, 1960). Predispersal seed predation could be high (Hesse et al., 2008) as it was detected for other species (e.g. Stachurska-Swakoń et al., 2018). The species is also capable of vegetative reproduction by producing buds on rhizome (Schaeffner et al., 2001). The plant parts contain a high concentration of alkaloids and are toxic to the animals, however it changes during vegetation season (Chmiel, 1985; Broda \& Mowszowicz, 2001).

Veratrum lobelianum belongs to the group of mountain species, it represents the Euro-Siberian element and oc- curs in the mountain ranges of the Alps, the Carpathians, the Sudetes in Europe and in Asia it in the north and after a significant disjunction in the Caucasus and the mountains of Central Asia (Meusel et al., 1965). Apart from the mountains, it is found in southern Poland (Silesian Upland, Małopolska Upland, Roztocze; Zając \& Zając, 2001). It has dispersed locations in Lithuania, Belarus, Finland, and Norway. The optimum altitude for the species is over 800 $\mathrm{m}$ above sea level, mainly on the upper montane and subalpine zone. It is a diagnostic species of the order Calamagrostidetalia villosae, it grows in tall-grass (Poo chaixiVeratrum lobeliani) and tall-herb communities (Adenostyletalia alliariae).

\subsection{The studied populations and statistical analyses}

The study was carried out in the Tarnów Plateau (Sandomierz Basin, southern Poland). The localities of the species were found after Wayda's "Flora of Tarnów Plateau" (Wayda, 1996) and our own observation (Jarek \& StachurskaSwakoń, 2016). Contemporary, three localities of the species were found in the Tarnów Plateau and all of them were taken into the study: population in Lipie, Jastrząbka, and Smyków. The localities Jastrząbka and Smyków were not published before. Forest Lipie is actually part of the Tarnów agglomeration, it is located in the north-east part of the Tarnów. Plant community in Lipie represents broadleaved forest: Tilio-Carpinetum association. Jastrząbka and Smyków are located in the area of Dąbrowa Tarnowska forestry district and both represent forest communities from Alno-Padion alliance. The localities differed in habitat conditions connected with the forest type: Lipie was the most shadowed locality, Smyków was the moistest. The climatic condition in the area of Tarnów Plateau resulted from its location in the Sandomierz Region climatic zone with an average annual temperature of $8^{\circ} \mathrm{C}$ and average annual rainfall 600-700 mm (Obrębska-Starklowa \& Leśniak, 1988).

30 randomly distributed individuals with generative shoots were selected in each location. The number of individuals for the study was chosen according to the small number of flowering individuals in the studied populations. The height of the aboveground part of the shoot (from the ground level to the end of inflorescence) and the length of inflorescence was measured. The number of leaves per shoot was counted. Length and width were measured for the lowest and fifth leaf (counted from the surface level). All measures were taken on alive plants growing in the wild. 20 capsules from every locality were collected (randomly) for the experiment of germination power. Half of the seeds were stored at room temperature and half of them were exposed to stratification $\left(-14^{\circ} \mathrm{C}\right) .40$ seeds from each locality were sown after two, four and six months from the collection time. The field study was conducted at the 
beginning of September 2010. The time for study was chosen on the base of observation of species phenology in this area.

The differences of measured data between localities were checked using non-parametric Kruskal-Wallis test. The correlations between traits of plants in the dataset were tested with linear regression and polynomial regression. All analyses perfrmed using Statistica softwere.
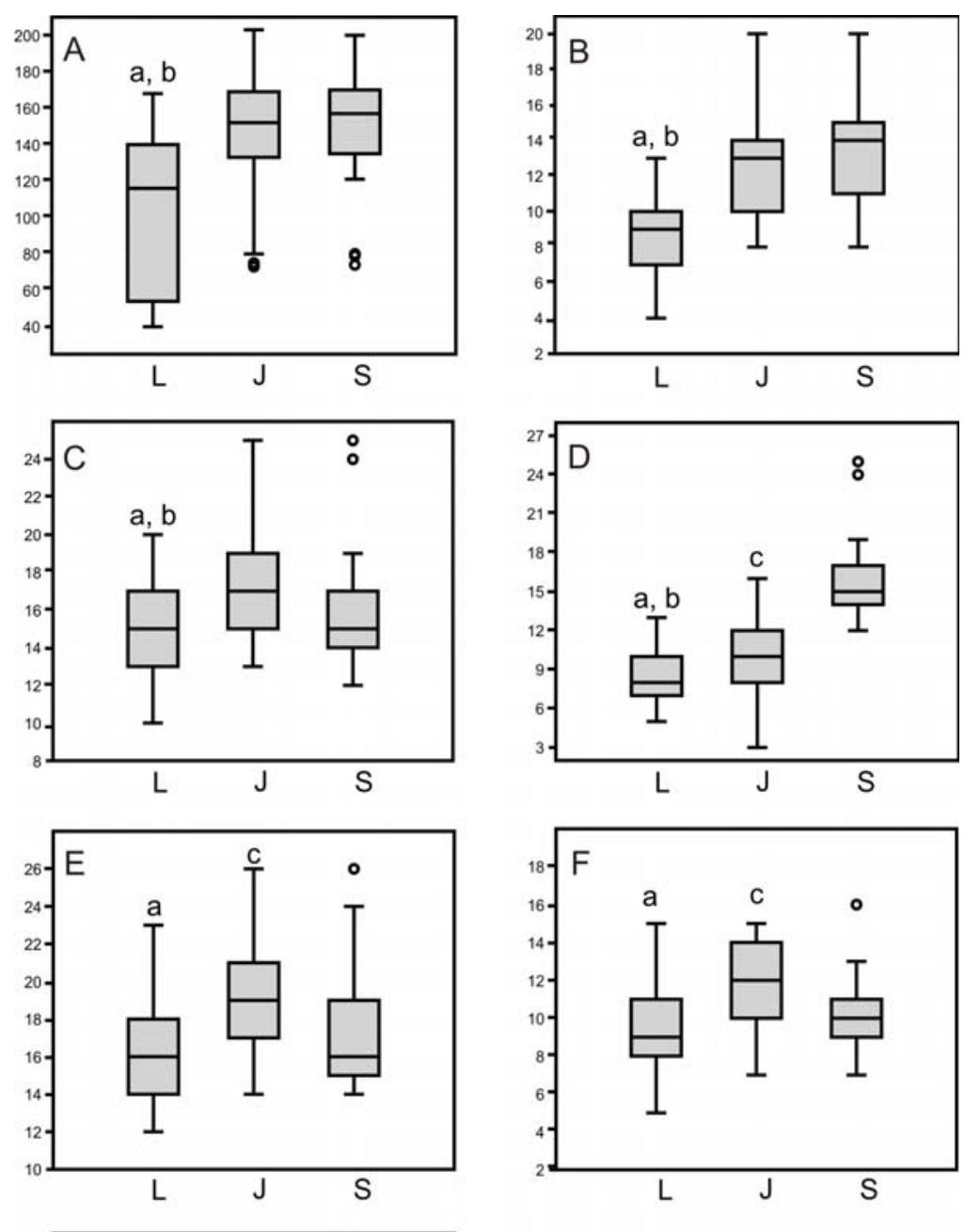

\section{Results}

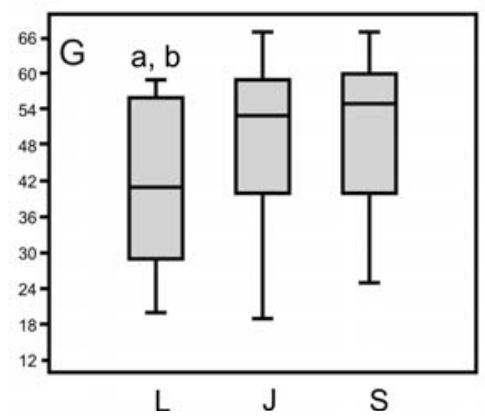

Veratrum lobelianum was found in three locations in the area of Tarnów Plateau. The localities differed in the population richness: in Lipie we counted about 300 individuals, in Jastrząbka 40 individuals, in Smyków more than 400.

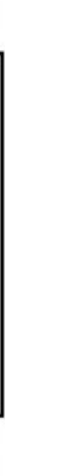


Vegetative individuals were numerous in all populations and the frequency of flowering individuals was low.

The height of the $V$. lobelianum specimens was highly variable and ranged from $40 \mathrm{~cm}$ (Lipie) to $203 \mathrm{~cm}$ (Jastrząbka). It was the statistically significant difference between Lipie and Jastrząbka as well as between Lipie and Smyków (Fig. 1A). The lowest mean was observed in the Lipie and the highest in the Smyków population. The standard deviation was very high in Lipie, however, this trait fulfilled the assumption of the normal distribution.

The generative shoots had from 4 to 20 leaves. The smallest number of leaves was observed in the Lipie population with the mean of 8.5. The highest number of leaves was found on specimens in the Smyków population with the mean of 13.6 (Fig. 1B). The significant differences between means were for Lipie - Jastrząbka and Lipie Smyków. The number of leaves was positively correlated with the height of plant (Fig. 2A) when taking into account all specimens and it was described by the second-order polynomial model $\left(y=x^{2}-0.05 x+8.2, R^{2}=0.8, p<0.001\right)$. The length of the lowest leaf was significantly different between Lipie - Jastrząbka and Lipie - Smyków. The means were from $14.8 \mathrm{~cm}$ in Lipie to $17.8 \mathrm{~cm}$ in Jastrząbka (Fig. 1C). The width of the lowest leaf was correlated with length and means ranged from $8.5 \mathrm{~cm}$ in Lipie to $10.3 \mathrm{~cm}$ in Jastrząbka (Fig. 1D). This correlation checked for all data was described by the linear regression $y=0.58 x+0.07$, $\mathrm{R}^{2}=0.75(\mathrm{p}<0.001)$. Similarly, the fifth leaf was the short-

A

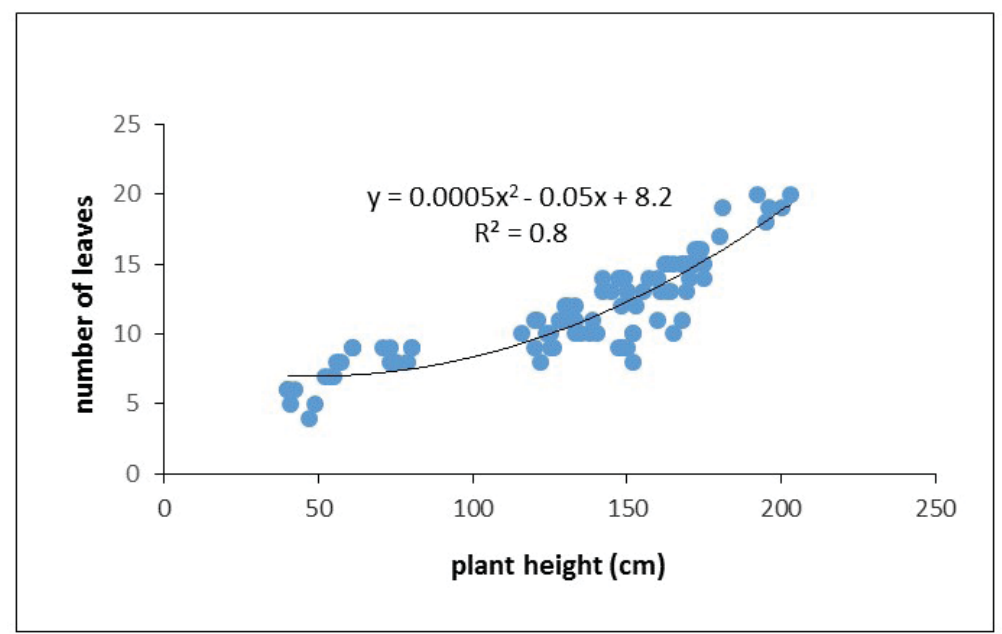

B

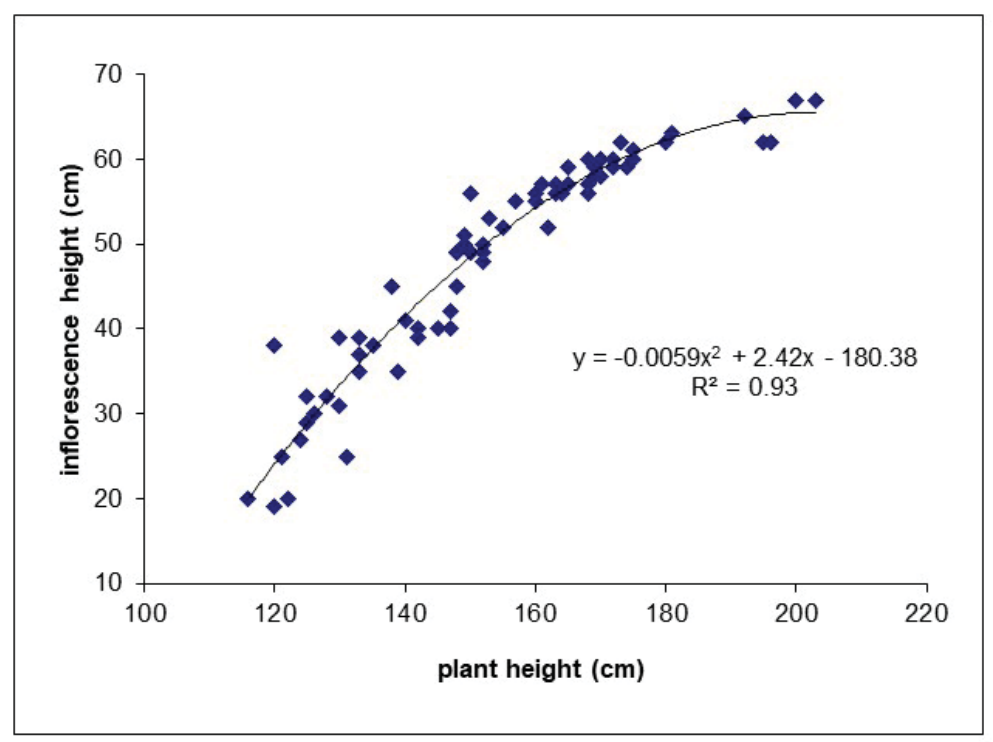

Figure 2. Relationship between height of Veratrum lobelianum and leaves number (A) and length of inflorescence (B). KruskalWallis test with $\mathrm{p}<0.001$ 
est and narrowest in Lipie (16.2 cm, $9.7 \mathrm{~cm}$ respectively), the longest and widest in Jastrząbka $(19.2 \mathrm{~cm}, 11.6 \mathrm{~cm})$ (Fig. 1E, 1F). The length of the leaf was positively correlated with the width $\left(\mathrm{y}=0.6 \mathrm{x}+0.06, \mathrm{R}^{2}=0.72, \mathrm{p}<0.001\right)$. The length-to-width ratio of the lowest leaf does not differ significantly between the stands and was on average 1.72 . Similarly, this value does not differ between the localities for fifth leaf and the average was 0.54 .

The longest inflorescences were observed at the stand in Smyków with an average of $54.8 \mathrm{~cm}$, and the lowest in Lipie: 41.6 (Fig. 1G). A significant difference in the height of the inflorescence was between Lipie and Smyków as well as Lipie and Jastrząbka. It was the positive correlation between inflorescence length and plant height. This relationship was the best described by a second-order polynomial (Fig. 2B, $\mathrm{a}_{1}=-0.006, \mathrm{a}_{2}=2.41 \mathrm{~b}=-180.38, \mathrm{R}^{2}=0.92$, $\mathrm{p}<0.001)$.

The mean number of seeds per collected capsule was 14 in Smyków population and 12 in Jastrząbka and Lipie. The difference between localities was not significant. The experiments with the seeds were negative, as the seeds did not germinate.

\section{Discussion}

In mountain conditions, Veratrum lobelianum usually grows in open areas: natural grasslands, tall-grass, and tall-herb communities (Pawłowski, 1972; Łukaszyńska, 1998). Lowland populations of the species were found in the forest communities: in the oak-hornbeam forest, mainly moist variant (Carpinion betuli alliance) and in alder carrs (Alno-Padion alliance) or rarely in wet meadows (Gawłowska et al., 1987; Bróż \& Przemyski, 1988; Nowak et al., 2011). From the literature, it can be assumed that for the occurrence of the species, the high level of groundwater and high abundance of nutrients are important (Bróż \& Przemyski, 1988; Łukaszyńska, 1998; Chmura et al., 2011). The size of the lowland populations was reported differentiated: from several individuals to several thousand extended in large areas (Bróż \& Przemyski, 1988). The populations studied on the Tarnów Plateau were growing in both types of forest communities: Lipie is a moist subassociation of the oak-hornbeam forest, Smyków and Jastrząbka represent alder carr. Based on the observation, it can be assumed that the soil and microclimatic conditions are sufficient for the occurrence of the species. The abundant population in Lipie and Smyków allow us to hope for the preservation of the population, assuming no drastic changes in habitat conditions. The Lipie forest, situated in the Tarnów agglomeration, is particularly valuable due to the high diversity of plants, however, it is also more vulnerable to the pressure of man's activity (Jarek \& Stachurska-Swakoń, 2016).
Phenotypic plasticity has been defined as a change in the phenotype expressed by a single genotype in different environments and is considered one of the major means that plants can cope with habitat variability (Gratani, 2014). V. lobelianum seems to be one of the species with the wide ecological spectrum as it is found in wide range of climatic condition (from lowland to subalpine zone), light conditions (open areas and shadowed forest). However, the edaphic parameters influence morphological traits of the species. Łukaszyńska (1998) studied in details 16 populations of the species in the Sudeten Mts representing different microclimatic, soil and coenotic conditions. Based on results she pointed the existence of ecotypes that differed in morphological features, i.e. height of generative stems, leaves number, length of inflorescence being the response to habitat factors (mainly edaphic features). She found the positive correlation between the content of $\mathrm{Mg}, \mathrm{Ca}$, and $\mathrm{pH}$ of soil and height of the plants and length of the inflorescence. In the studied Sudeten populations, the height of generative shoots was in the range from 24 to $186 \mathrm{~cm}$ with the average highest $136 \mathrm{~cm}$ out of 16 studied populations. The length of the inflorescence ranged from 6 to $72 \mathrm{~cm}$ and it was a trait with quite a high variability, with the highest average of $48 \mathrm{~cm}$. The number of leaves varied from 4 to 17 with the highest average 12 . These values are lower than those observed on the Tarnów Plateau. The obtained results and their comparison with the results for mountain populations indicate the high phenotypic plasticity of the species. Similar results referring to plant height: lower in mountain conditions, higher in lowland localities, were observed for Doronicum austriacum (Stachurska-Swakoń \& Kuź, 2011). Both species, i.e. Doronicum austriacum and Veratrum lobelianum, are subalpine (or multizonal) plants, often growing together in tall-herb communities (e.g. Stachurska-Swakoń, 2008) and sometimes together in lowland forest localities (Czylok \& Stanek, 2000; Chmura et al., 2011). The phenomenon of taller plants under shadow conditions is the result of modifications of morphological features under conditions of lower light availability. On the other hand, observations of other authors (Kleijn \& Steinger, 2002; Hesse et al., 2008) proved that in grazed pastures the unpalatable stems of Veratrum album might attain the considerable height in effect of favorable light conditions. Also, the laboratory experiments conducted in Veratrum californicum (Sun et al., 2013) proved, that the supplemental light initially enhanced the increase of stem height. Our results showed the highest individuals of $V$. lobelianum in the population located in Smyków - locality, where the considerable soil humidity was recorded. Simultaneously, it should be pointed out, that phenomenon observed in populations of $V$. lobelianum correspond with the scenario found in other plant taxa occurring in lowlands. They create higher generative stems in habitats overgrown by trees, shrubs, and macroforbs characterizing by sub- 
stantial soil humidity, than in open sunny habitats such as meadows or calcareous grasslands dominated by lowstatured species. Such phenomenon was observed in many herbaceous species i.e. Gladiolus imbricatus (Kubikova \& Zeidler, 2011; Kostrakiewicz-Gierałt, 2014), Gentiana pneumonanthe (Kostrakiewicz, 2013), Filipendula vulgaris (Kostrakiewicz-Gierałt \& Stachurska-Swakoń, 2017). Summarizing, our findings correspond with the conventional wisdom assuming that plant height is one of the traits, which are mostly depending on habitat conditions (Harper, 1977).

The greatest number of leaves was observed in the population located in Smyków and the average was higher than in the Sudeten populations (13.6 versus 12). It can be assumed that a greater number of leaves is the result of the most favorable soil conditions: soil moisture and soil content. It was observed, that when plants grow under low irradiance but with mineral nutrient and water supply it resulted in increased growth, SLA or aboveground dry mass (e.g. Peace \& Grubb, 1982; Quinet et al., 2015; Barabasz-Krasny et al., 2018). Increasing leaf area and maintaining integrity of photosystems under low-light condition is a way to maximize light acquisition (Quinet et al., 2015). The high number of leaves and its dimensions in studied forest populations of $V$. lobelianum could be the adaptation to low irradiation under good soil condition. The highest number of leaves in forest conditions is in contradiction with the observations of another subalpine species growing in lowlands Doronicum austriacum (Stachurska-Swakoń \& Kuź, 2011). More favorable soil conditions result in higher plants with bigger leaves also longer inflorescences. The positive correlation of plant height and inflorescence length confirms the results obtained by Łukaszyńska (1998). Longer inflorescences are likely to produce a larger number of flowers - although this trait has not yet been studied in the $V$. lobelianum. A very interesting result is the dependence of the second-order polynomial: at a certain height of plants (here about 170 $\mathrm{cm}$ ), the length of the inflorescence does not increase proportionally. Whether this relationship is a general rule for the species it requires further research. Moreover, observations conducted in populations of $V$. album showed, that individuals growing on nutrient-rich pastures have a larger overall size, size of inflorescence and ultimately seed output per year than plants growing on poor soils (Schaffner et al., 2001). Plant size and the size-dependence of traits define important relationships between form and function (Niklas, 2004). Allocation to reproduction is a key aspect of plant adaptive strategies across environments (Bonser \& Aarsen, 2009; Weiner et al., 2009; Bonser, 2013).

Experiments with seed sowing were inspired by observations of other Veratrum species that required a different time of freezing to germinate (even up to 4.5 months) (Taylor, 1956). However, lack of germination of $V$. lobeli- anum in the artificial conditions confirms the observations of Czaplińska (1953) about the need for mycorrhizal fungi to start germination. The experiments with seed sowing in the field on $V$. album pointed at the considerable change in the consecutive years showing that the species forms a short-term persistent seed bank (Hesse et al., 2007).

\section{Conclusion}

The present results demonstrate the ability of Veratrum lobelianum to grow under different habitat conditions. In the similar climatic conditions but varied light and soil conditions, the species populations produce statistically different aboveground shoots. It is compatible with the statement of Łukaszyńska (1998) that the species could create ecotypes. We can assume that the soil conditions, in particular humidity, are the most important for the plant growth and reproduction (both generative and vegetative) as the size of the population, plant height, leave number, leave dimensions, length of inflorescence and seed production was the highest in Smyków locality. This results also show the ability of the species to maximize the light acquisition under low irradiance. Its phenotypic plasticity could be treated as optimistic in the light of the global climatic change that negatively influences on distribution and occurrence of mountain species (e.g. Kelly \& Goulden, 2008; Dirnböck et al., 2011; Solár \& Janiga, 2013).

\section{References}

Banach B., 2008, Rare and protected species in the drainage ditches and adjacent phytocoenoses in the Polesie National Park. Acta Agrobotanica 61(2): 103-111.

Barabasz-Krasny B., Możdżeń K., Sołtys-Lelek A. \& Stachurska-Swakoń A., 2018, Biological traits of Impatiens parviflora DC. under different habitat conditions. Notulae Botanicae Horti Agrobotanici 46(1): 277-285.

Bartoszek W., Barci K. \& Stachurska-Swakoń A., 2015, Mountain species in the flora of the Sopotnia Wielka creek (Western Beskids, Poland). Acta Musei Silesiacae Sciences Naturae 64(3): 269-273.

Błaszczyk H., 1959, Flora powiatu włoszczowskiego [Flora of the district of Włoszczowa (Southern Poland)]. Fragmenta Floristica et Geobotanica 5(1): 47-96.

Bonser S.P., 2013, High reproductive efficiency as an adaptive strategy in competitive environments. Functional Ecology 27: 876-885.

Bonser, S.P. \& Aarssen, L.W., 2009, Interpreting reproductive allometry: individual strategies of allocation explain size-dependent reproduction in plant populations. Perspectives in Plant Ecology, Evolution and Systematics 11: 31-40. 
Broda B. \& Mowszowicz J., 2001, Przewodnik do oznaczania roślin leczniczych trujących i użytkowych. PZWiL, Warszawa.

Bróż E. \& Przemyski A., 1988, Gatunki ciemiężyc Veratrum L. sp., rosnące w Polsce, ich stopień zagrożenia i stan ochrony. Chrońmy Przyrodę Ojczystą 6: 24-37.

Chmiel J., 1985, Ciemiężyca zielona Veratrum lobelianum zjadana przez owce na Rusinowej Polanie w Tatrzańskim Parku Narodowym. Chrońmy Przyrodę Ojczysta 4: 44-46.

Chmura D., Molenda T., Błońska A. \& Woźniak G., 2011, Sites of leachate inflows on coalmine heaps as refuges of rare mountainous species. Polish Journal of Environmental Studies 20(3): 551-557.

Ciaciura M., 1988, Charakterystyka rozmieszczenia górskich gatunków naczyniowych na Śląsku. Rozprawy Habilitacyjne Akademii Medycznej we Wrocławiu 12(1): 1-157, (2): 1-204.

Czaplińska S., 1953, Badanie rocznej dynamiki rozwojowej mykorhizy ciemiężycy i zimowita jesiennego. Ekologia Polska 1(4): 126-132.

Czylok A. \& Stanek J., 2000, The stand of Doronicum austriacum Jacq. in Katowice. Natura Silesiae Superioris 4: 5-7.

Dirnböck T., Essl F. \& Rabitsch W., 2011, Disproportional risk for habitat loss of high-altitude endemic species under climate change. Global Change Biology 17(2): 990-996.

Gawłowska J., Janeczko Z., Przeniosło I. \& Szpakowska M., 1987, Stanowiska ciemiężycy zielonej Veratrum lobelianum i lilii złotogłów Lilium martagon w granicach Krakowa. Chrońmy Przyrodę Ojczystą 43(4): $57-$ 61.

Gleason H.A. \& Cronquist A., 1991, Manual of vascular plants of northeastern United States and adjacent Canada. NewYork, New York Botanical Garden.

Gratani L., 2014, Plant phenotypic plasticity in response to environmental factors. Advances in Botany, Article ID 208747.

Harper J.L., 1977, Population biology of plants. Academic Press, London.

Hess H.E., Landolt E. \& Hirzel R., 1967, Flora der Schweiz. Basel, Switzerland, Birkhaeuser Verlag.

Hesse E., Rees M. \& Müller-Schärer H., 2007, Seed bank persistence of clonal weeds in contrasting habitats: implications for control. Plant Ecology 190: 233-243.

Hesse E., Rees M. \& Müller-Schärer H., 2008, Life-history variation in contrasting habitats: flowering decisions in a clonal perennial herb (Veratrum album). The American Naturalist 172(5): 196-213.

Izdebska M., 1963, Rzadsze rośliny łąk górnego odcinka Wieprza [Seltenere Wiesenpflanzen im Tale des oberen Wieprzflusses (SO-Polen)]. Fragmenta Floristica et Geobotanica 9(4): 455-462.
Jakubowska-Gabara J. \& Jost-Jakubowska B., 1978, Element górski we florze Polski środkowej [Mountain element in the Central Poland Flora]. Fragmenta Floristica et Geobotanica 24: 259-272.

Jakubowska-Gabara J., Kurzac M., Kiedrzyński M., Kopeć D., Kucharski L., Kołodziejek J., Niedźwiedzki P., Popkiewicz P., Witosławski P. \& Zielińska K., 2012, Nowe stanowiska rzadkich, chronionych i zagrożonych gatunków roślin naczyniowych w Polsce Środkowej. Cz. II [New stations of rare, protected and threatened species of vascular plants in Central Poland. Part II]. Fragmenta Floristica et Geobotanica Polonica 19(2): 349-359.

Jarek S. \& Stachurska-Swakoń A., 2016, Flora okolic Tarnowa (Kotlina Sandomierska) [The flora of the Tarnów area (Kotlina Sandomierska basin)]. Fragmenta Floristica et Geobotanica Polonica 23(2): 243-254.

Kelly A.E. \& Goulden M.L., 2008, Rapid shifts in plant distribution with recent climate change. PNAS 105(33): 11823-11826.

Kleijn D. \& Steinger T., 2002, Contrasting effects of grazing and hay cutting on the spatial and genetic population structure of Veratrum album, an unpalatable, longlived, clonal plant species. Journal of Ecology 90(2): 360-370.

Kornaś J. \& Medwecka-Kornaś A., 2002, Geografia roślin. Wydawnictwo Naukowe PWN, Warszawa.

Kostrakiewicz K., 2013, The effect of vegetation character on abundance and structure of subpopulations of rare herb species Gentiana pneumonanthe L. Polish Journal of Ecology 61(1): 35-43.

Kostrakiewicz-Gierałt K. \& Stachurska Swakoń A., 2017, The influence of habitat conditions on the abundance and selected traits of the rare medicinal plant species Filipendula vulgaris Moench. Ecological Questions 25: 9-18.

Kostrakiewicz-Gierałt K., 2014, The variability of selected features of Gladiolus imbricatus L. in relation to successive stages of meadow communities following the mowing cessation. Polish Journal of Ecology 62: 307321.

Kowalczyk T., 2012, Rzadkie i interesujące gatunki roślin naczyniowych okolic Libiąża (Wyżyna Śląska). Fragmenta Floristica et Geobotanica Polonica 19(1): 177200.

Kubikova P. \& Zeidler M., 2011, Habitat demands and population characteristics of the rare plant species Gladiolus imbricatus L. in the Frenštát region (NE Moravia, the Czech Republic). Časke Slezke Muzeum Opava 60: 154-164.

Kuczyńska I., 1974, Stosunki geobotaniczne Opolszczyzny. II. Analiza geograficzna flory. Podział geobotaniczny [Geobotanical relations of the Opole region. II. Geographical analysis of the flora. Geobotanical divi- 
sion]. Acta Universitatis Wratislaviensis 216. Prace Botaniczne 18: 1-115.

Lauber K. \& Wagner G., 1996, Flora Helvetica. Bern, Switzerland, Verlag Paul Haupt.

Łukaszyńska I., 1998, Ekologia populacji Veratrum lobelianum Bernh. w Sudetach [Ecology of Veratrum lobelianum Bernh. in the Sudetes]. Acta Universitatis Wratislaviensis No 2090, Prace Bot., 77: 125-204.

Meusel H., Jager E. \& Weinert E., 1965, Vergleichende Chorologie der Zentraleuropaischen Flora. Jena: Veb Gustav Fischer Verlag. Bd. I..

Michalik S., 1983, Rozmieszczenie roślin kserotermicznych i górskich w Ojcowskim Parku Narodowym w zależności od warunków mikroklimatu [Distribution of xerotermal and montane plants in the Ojców National Park depending on microclimatic conditions]. Studia Naturae 24: 1-74.

Mirek Z., Piękoś-Mirkowa H., Zając A. \& Zając M. (eds), 2002, Flowering plants and pteridophytes of Poland. A checklist. Biodiversity of Poland 1., W. Szafer Institute of Botany. Polish Academy of Sciences, Kraków.

Mitka J., 1997, Małe izolowane populacje na skraju zasięgu geograficznego - niektóre procesy ekologiczne i genetyczne [Small, isolated plant populations at geographical range borders - some ecological and genetic processes]. Wiadomości Botaniczne 41: 13-34.

Niklas K.J., 2004, Plant allometry: is there a grand unifying theory? Biological Review 79: 871-889.

Nowak T., Urbisz A., Kapusta P. \& Tokarska-Guzik B., 2011, Distribution patterns and habitat preferences of mountain vascular plant species in the Silesian uplands (southern Poland). Polish Journal of Ecology 59(2): 219-234.

Obrębska-Starklowa B. \& Leśniak B., 1988, Klimat, [in:] J. Warszyńska (ed.), Województwo tarnowskie. Monografia. Zakład im. Ossolińskich. Wyd. PAN, Wrocław, Warszawa, Kraków, Gdańsk, Łódź, 42: pp. 29-30.

Parusel J., 2016, „Nowe” gatunki górskie ze Śląska na niżu Polski ["New" mountain species from Silesia in the Polish lowlands]. Fragmenta Floristica et Geobotanica Polonica 23(2): 273-288.

Pawłowska S., 1972, Charakterystyka statystyczna i elementy flory polskiej. [in:] W. Szafer \& K. Zarzycki (eds), Szata roślinna Polski, vol. 1. Państwowe Wydawnictwo Naukowe, Warszawa: 129-206.

Pawłowski B., 1972, Zespoły wysokogórskie, [in:] W. Szafer, K. Zarzycki (eds), Szata roślinna Polski, vol. 1. Państwowe Wydawnictwo Naukowe, Warszawa: 366-382.

Peace W.J.H. \& Grubb P.J., 1982, Interaction of light and mineral nutrient supply in the growth of Impatiens parviflora. New Phytology 90: 127-150.

Pierścińska A., 2012, Stanowiska rzadkich i interesujących gatunków roślin naczyniowych we wschodniej części
Pogórza Szydłowskiego (Wyżyna Kielecka) [Localities of rare and interesting vascular plants in the eastern part of the Szydłów Foothills (Kielce Upland)]. Naturalia 1: $62-70$.

Quinet C.D., Coster Q., Lutts S. \& Jacquemart A-L., 2015, Tolerance to water stress and shade in the invasive Impatiens parviflora. Int. Journal of Plant Sciences 176(9): 848-858.

Schaffner U., Kleijn D., Brown V. \& Müller-Schärer H., 2001, Veratrum album in montane grasslands: a model system for implementing biological control in land management practices for high biodiversity habitats. Biocontrol News and Information 22(1): 19-28.

Solár J. \& Janiga M., 2013, Long-term changes in dwarf pine (Pinus mugo) cover in the High Tatra Mountains, Slovakia. Mountain Research and Development 33(1): 51-62.

Stachurska-Swakoń A., 2008, The role of Athyrium distentifolium Tausch ex Opiz in formation of tall-herb communities in the Tatra National Park (the Western Carpathians), [in:] E. Szczęśniak, E. Gola (eds), Club mosses, horsetails and ferns in Poland - resourses and protection. Polish Botanical Society \& Institute of Plant Biology, University of Wrocław, Wrocław: 81-94.

Stachurska-Swakoń A. \& Kuź K., 2011, Phenotypic response of Doronicum austriacum Jacq. (Asteraceae) to diverse mountain and lowland conditions. Polish Journal of Ecology 59(2): 249-262.

Stachurska-Swakoń A., Cieślak E. \& Ronikier M., 2011, Genetic variability of small isolated population of $\mathrm{Ci}$ cerbita alpina (L.) Wallr. in the Beskid Mały Mts (Southern Poland). Polish Journal of Ecology 59(2): 279-288.

Stachurska-Swakoń A., Cieślak E. \& Ronikier M., 2012, Phylogeography of subalpine tall-herb species in Central Europe: the case of Cicerbita alpina (L.) Wallr. Preslia 84(1): 121-140.

Stachurska-Swakoń A., Barabasz-Krasny B., Klasa A. \& Palaczyk A., 2018, Reduced plant fitness by pre-dispersal seed predation in the threatened plant species Cirsium decussatum. Seed Science Research 28(2): 1-8.

Sun Y., White S., Mann D. \& Adelberg J., 2013, Photosynthetic characteristics of Veratrum californicum in varied greenhouse environments. Journal of Medicinally Active Plants 1(4): 134-142.

Szafer W., 1930, Element górski we florze niżu polskiego [The mountain element in the flora of the Polish lowlands]. Rozprawy Wydziału Matematyczno-Przyrodniczego, Polska Akademia Umiejętności, Serja 3, Dział B, 69: 1-112.

Szafer W., Kulczyński S. \& Pawłowski B., 1986, Rośliny polskie. Państwowe Wydawnictwo Naukowe, Warszawa. 
Szwagrzyk J., 1987, Flora naczyniowa Niecki Nidziańskiej [Vascular plants of the Nida Basin]. Studia Ośrodka Dokumentacji Fizjograficznej PAN 15: 17-71.

Takhtajan A.L. (ed), 1982, Žizń rastenij. Prosveščenie, Moskva.

Taylor C.A., 1956, The culture of false hellebore. Economic Botany 10: 155-65.

Urban D. \& Wójciak H., 2012, Interesting vascular plant species in the Bug River Valley (Gołębie-Kostomłoty Section). Teka Komisji Ochrony i Kształtowania Środowiska Przyrodniczego 2(9): 234-250.

Urbisz A., 2001, Gatunki górskie we florze naczyniowej Płaskowyżu Rybnickiego (Wyżyna Śląska). [The mountain species in the vascular flora of the Rybnik Plateau (Silesian Upland)]. Fragmenta Floristica et Geobotanica Polonica 8: 63-70.

Varienik I.P., 1960, O prastaniju semjan Veratrum lobelianum. Botaniceskij Żurnal 7: 1340-1341.

Wayda M., 1996, Rośliny naczyniowe Płaskowyżu Tarnowskiego (Kotlina Sandomierska). Zeszyty Naukowe
Uniwersytetu Jagiellońskiego, Prace Botaniczne 29: 1-132.

Weiner J., Campbell L.G., Pino J. \& Echarte L., 2009, The allometry of reproduction within plant populations. Journal of Ecology 97: 1220-1233.

Zając M., 1996, Mountain vascular plants in the Polish Lowlands. Polish Botanical Studies 11: 1-92.

Zając A. \& Zając M., (eds) 2001, Distribution atlas of vascular plants in Poland. Laboratory of Computer Chorology, Institute of Botany, Jagiellonian University, Cracow.

Zając M., Zając A. \& Zemanek B. (eds), 2006, Flora Cracoviensis Secunda (atlas). Nakładem Pracowni Chorologii Komputerowej Instytutu Botaniki Uniwersytetu Jagiellońskiego, Kraków.

Zemanek B., 2009, Fitogeograficzne problemy Karpat [Phytogeographical problems of the Carpathians]. Roczniki Bieszczadzkie 17: 43-58. 